\title{
Korte, begeleide meditatie heeft geen invloed op intra- en \\ interpersoonlijke EEG coherentie en hartslagfrequentie van ongeoefende studenten
}

Ondertitel:

Een onderzoek naar de fysiologische effecten van meditatie bij ongeoefende studenten,

Knipschild, J. ${ }^{1}$, Verhagen-Schouten, S. ${ }^{2}$

${ }^{1}$ Sectie Klinische Neuropsychologie, Vrije Universiteit Amsterdam

${ }^{2}$ Vrijgevestigd psychotherapeut Amsterdam

Correspondentieadres:

josephineknipschild@hotmail.com

\section{Samenvatting}

In deze studie werd de invloed van mindfulness op intra- en interpersoonlijke EEG correlaties en hartfrequentie onderzocht. De eerste onderzoeksvraag luidde: 'wordt de EEG correlatie tussen linker- en rechter hemisfeer in het brein van een individu beïnvloed tijdens meditatie? De tweede onderzoeksvraag luidde: gaat de hartfrequentie van een individu omlaag tijdens meditatie? De derde onderzoeksvraag luidde: wat gebeurt er met de EEG correlatie tussen de hersenactiviteit van twee individuen als zij tegelijk in meditatieve toestand zijn, tegelijk niet in meditatieve toestand zijn en als een van beide in meditatieve toestand is? Voor de derde onderzoeksvraag zijn de proefpersonen opgedeeld in zeven koppels. Er namen 14 studenten van de Vrije Universiteit in Amsterdam deel. De leeftijd varieerde van 19 tot 24 jaar $(M=$ 21.71, $S D=1.44)$. 
Er waren drie condities relevant voor dit onderzoek. De rust conditie gold als basismeting. Hierbij zat men gedurende vijf minuten stil met de ogen open. De tweede conditie betrof mindfulness, waarbij beide personen van een koppel een meditatie fragment van drie minuten te horen kregen. De laatste conditie was de 'mindfulness versus rekenen' conditie, waarbij de ene proefpersoon van het koppel het mindfulness fragment te horen kreeg, terwijl de andere proefpersoon een rekentaak uitvoerde.

Voor elk hersengebied werd het EEG van de linker en de rechter hemisfeer binnen en tussen deelnemers gecorreleerd en daarna werden de correlaties vergeleken tussen de condities. Binnen het individu is er tijdens meditatie voor geen enkel gebied een significante toename in EEG correlatie gevonden tussen de linker- en rechterhemisfeer. Daarnaast is alleen een trend van een afname in hartfrequentie gemeten binnen een individu tijdens meditatie. Er is tevens geen significant resultaat gevonden voor interpersoonlijke EEG correlatie tussen de algehele hersenactiviteit over de condities rust, mindfulness en 'mindfulness versus rekenen. Mogelijk was het aantal proefpersonen te gering of is het de proefpersonen niet gelukt in meditatieve toestand te komen.

\section{Inleiding}

De mens is een sociaal wezen dat reageert op zijn fysieke en sociale omgeving. Hierdoor beïnvloeden individuen elkaar tijdens sociale interactie. In de 'Social Brain Hypothesis' wordt er van uitgegaan dat de grootte van de hersenen van een primaat samenhangt met de omvang van de sociale omgeving. Beperkingen in (sociale) groepsgrootte kunnen dus samengaan met een kleinere informatieverwerkingscapaciteit van de hersenen. Enkele decennia geleden werd gevonden dat bij mensapen de neocortex ratio groter was naarmate de leefgroepen groter waren [1]. Nog eerder vonden Sawaguchi en Kudo [2] een positieve relatie tussen de grootte van de neocortex en de grootte van de groepen waarin werd geleefd bij verschillende primaten. De uitkomsten van primaatstudies zijn niet zomaar toepasbaar op de mens. Toch lijkt het plausibel dat sociale interacties ook bij mensen belangrijk zijn voor de ontwikkeling van het brein. 
Elektro-encefalografie (EEG) is een methode om menselijke hersenactiviteit te meten. Eén van de specifieke toepassingen van EEG registratie is om door middel van hersengolven de coherentie in het brein van een individu te meten. Met EEG coherentie kan men de lineaire afhankelijkheid tussen twee verschillende hersengebieden kwantitatief meten. Een hoge EEG coherentie betekent dat er een toename is van het functionele samenspel tussen de neurale netwerken [3]. Bij het meten van coherentie kan men onderscheid maken tussen intrapersoonlijke hersencoherentie en interpersoonlijke hersencoherentie [4-6].

Bij intrapersoonlijke hersencoherentie wordt de coherentie tussen twee specifieke gebieden of twee verschillende hemisferen in de hersenen van een individu berekend. Zo kan men de functionele specialisatie van de hersenen van een individu onderzoeken evenals de hersenactiviteit tijdens het creëren van representaties van de binnen- en buitenwereld [5]. Onderzoek naar intrapersoonlijke hersencoherentie kan een beeld geven van hoe de hersenen van twee verschillende groepen mensen reageren op specifieke taken en hoe de hersenen feitelijke informatie over de buitenwereld verwerken [7]. Uit een intrapersoonlijk hersencoherentie onderzoek naar verschillen tussen Gilles de la Tourette patiënten en controles bleek dat Tourette patiënten een verminderde hersenactivatie hadden in frontale en centrale gebieden tijdens motor taken. Daarnaast was een verminderde activatie tijdens muziek perceptie in de temporale en pariëtale gebieden te zien. Dit betekent dat er bij Tourette patiënten door de ziekte meer hersengebieden worden aangetast dan alleen motor gebieden [7]. In een recent onderzoek van Labooy Speksnijder et al. bleek dat mensen met een hogere score op de persoonlijkheidsfactor emotionaliteit ook een hogere correlatie in het EEG hebben tussen de linker en rechter hemisfeer [4].

Om het effect van sociale interactie tussen mensen op de hersenactiviteit te onderzoeken is het nuttig om ook de hersenactiviteit en coherentie tussen individuen te meten. Bij een EEG meting tussen individuen kan men onderzoeken hoe twee mensen elkaar beïnvloeden in hun gedrag, sociale interacties en sociale omgevingen. Dit meten tussen twee individuen wordt interpersoonlijk hersencoherentie onderzoek of 
hyperscanning genoemd [8]. Tot op heden is er relatief weinig onderzoek naar interpersoonlijke hersencoherentie gedaan. Uit een EEG onderzoek bij proefpersonen die met behulp van een camera en een computerscherm live elkaars handbewegingen imiteerden bleek dat interactionele synchronisatie correleerde met een interpersoonlijk brein synchroniserend netwerk bij de rechter centrale pariëtale gebieden. Deze gebieden zouden een rol spelen in sociale interactie [9]. Onderzoek van Coomans et al. liet zien dat coherentie tussen personen optreedt tijdens een korte mindfulness oefening, maar ook tijdens een oddball taak die onder stress werd uitgevoerd. Dit in tegenstelling tot een conditie waarbij geen stressfactor aanwezig was. In een vergelijkbaar onderzoek van Engelbregt et al. waarbij onervaren studenten eenvoudige begeleide meditatie doen bleek dat alleen sprake is van een significant intrapersoonlijk EEG effect wanneer twee onervaren studenten samen een eenvoudige begeleide meditatie doen. Dit in tegenstelling tot het alleen uitvoeren van de meditatie. In deze studie werd geen toename gevonden in interpersoonlijke EEG correlatie tijdens één van de taken [10]. Een ander hyperscanningonderzoek waarin proefpersonen face-to-face met elkaar communiceerden toonde een significante toename in neurale synchronisatie in de linker inferieure frontale cortex [11]. Tot slot toonde een hyperscanning onderzoek naar verbale communicatie tussen vriendinnen dat de tijd van neurale activiteit in gebieden geassocieerd met spraak productie gekoppeld was met de tijd van neurale activiteit in de auditieve cortex. Dit wijst erop dat neurale activiteit en synchronisatie stijgt tijdens sociale interacties [12].

Interpersoonlijke EEG coherentie kan vergroot worden door gezamenlijke meditatie, zoals mindfulness, dat gedefinieerd wordt als: 'De concentratie die nodig is om een stabiel aandachtsniveau vast te houden. In plaats van te focussen op één object, is het de bedoeling om vrijstaande observaties te hebben, van moment tot moment' [13]. Mindfulness betekent een constante aandacht voor voortdurende mentale inhoud zonder over deze mentale processen na te denken of te oordelen gedurende de beoefening van meditatie $[14,15]$. Chiesa [14] vond door middel van EEG onderzoek een significante toename in alpha en theta activiteit tijdens 
mindfulness meditatie.

Een andere vorm van meditatie is Transcendente Meditatie (TM), een proces dat door de volgende fases gaat: 1) een progressieve reductie van mentale en fysieke activiteit, 'inward stroke' genoemd; 2) complete mentale stilte waarin gedachten afwezig zijn, maar het bewustzijn behouden wordt. Dit wordt 'Transcendental Consciousness' genoemd; en 3) de progressieve toename van mentale en fysieke activiteit [16, 17]. In een hyperscanning studie vergeleken Travis en Wallace [17] een conditie van Transcendente Meditatie (TM) met een conditie van rust met gesloten ogen. Resultaten toonden dat personen in de TM conditie een tragere hartslag hadden en hogere frontale EEG coherentie tijdens de meditatie in vergelijking met de personen in rust met gesloten ogen. Deze resultaten suggereren dat de toestand van TM tot een significant andere toestand leidt dan de toestand in rust met gesloten ogen.

Daarnaast bleek dat de verandering in toestand binnen één minuut na aanvang van de TM plaatsvond en tijdens de gehele meditatie stand hield. TM lijkt dus iets anders dan 'gewoon stil zitten' en lijkt voor meer coherentie in de hersenen te zorgen.
Weer een andere vorm van meditatie is Buddhist Meditatie. In deze vorm van meditatie gaat men via concentratie op een glazen bal weg van alle afleidingen en komt zo in een optimale concentratie in het nu [18]. Uit onderzoek van Sudsuang et al. [18] bleek dat de groep die mediteerde significant tragere hartslagen kreeg na drie en na zes weken beoefening van de meditatie. Voorafgaand aan het onderzoek waren er nog geen significante verschillen. Hartfrequentie is een belangrijke fysiologische graadmeter van de menselijke gezondheid. Uit onderzoek is gebleken dat een verhoogde hartfrequentie leidt tot een verhoogde kans op cardiovasculaire ziekten. Een verlaging van de hartfrequentie kan deze kans doen afnemen [19].

Uit voorgaande onderzoeken $[14,17,18]$ blijkt dat verschillende vormen van meditatie kunnen zorgen voor een toename van de intrapersoonlijke coherentie in de hersenen en voor een lagere hartfrequentie. Er is nog geen onderzoek gedaan naar de invloed van meditatie op interpersoonlijke EEG coherentie.

Het onderstaande onderzoek ging de invloed na van mindfulness meditatie op 
intra- en interpersoonlijke EEG coherentie.

Daarnaast werd de hartfrequentie gedurende het onderzoek gemeten. Bij de intrapersoonlijke EEG coherentiemeting werd de vraag gesteld of de coherentie tussen de linker- en rechterhemisfeer in bepaalde hersengebieden toeneemt tijdens meditatie. Bovendien werd nagegaan of de hartfrequentie van een individu omlaag gaat tijdens meditatie.

Bij de interpersoonlijke EEG coherentiemeting werd de vraag gesteld wat er met de coherentie tussen de globale hersenactiviteit van twee individuen gebeurt als deze wel mediteren, niet mediteren of als één individu wel mediteert en de ander niet. Als een toename van EEG coherentie in de hersenen gepaard gaat met een verlaging van de hartfrequentie, zou dat een bevestiging geven van het positieve effect van een toename van EEG coherentie [20].

De verwachting was dat EEG coherentie binnen een individu toeneemt tijdens meditatie en de hartfrequentie daalt.

De verwachting voor de interpersoonlijke hersencoherentie was dat de EEG coherentie tussen personen sterk toeneemt als twee individuen in meditatieve toestand zijn, licht toeneemt als twee personen niet in meditatieve toestand zijn en daalt als slechts één van beiden in meditatieve toestand is.

\section{Methode}

Als maat voor coherentie werd de correlatie berekend. Correlatie is de oude manier van het meten van coherentie, dus deze twee maten zijn goed met elkaar te vergelijken.

\section{Participanten}

Er namen 14 proefpersonen deel aan het onderzoek. Allen waren studenten Psychologie aan de Vrije Universiteit (VU) in Amsterdam. De groep proefpersonen bestond uit 4 mannen en 10 vrouwen. De leeftijden varieerden van 19 tot 24 jaar, met een gemiddelde van 21.71 jaar $(S D=$ 1.44). Alle proefpersonen waren Nederlands sprekend. Van de 14 proefpersonen waren 3 personen linkshandig (1 man) en 11 personen rechtshandig. De proefpersonen hadden geen ervaring met meditatie.

\section{Materialen}

Voor de EEG metingen is een Deymed Truscan 32q EEG-System met 32 kanalen 
gebruikt (4,096 Hz per kanaal). Daarnaast is een Spandex elektrodencap gebruikt met 19 elektroden (Electrocap International Inc.). In Figuur hieronder worden de verschillende locaties aangegeven die gemeten zijn. Elke letter geeft een specifiek hersengebied aan; $\mathrm{A}=$ oorlel, $\mathrm{C}=$ centraal, $\mathrm{P}=$ pariëtaal, $\mathrm{F}=$ frontaal, $\mathrm{Fp}=$ frontaal polaire en $\mathrm{O}=$ occipitaal. $\mathrm{De}$ oneven nummers achter de letters zijn de locaties aan de linkerzijde van de schedel, de even getallen geven de rechterzijde van de schedel weer. Aan de linker oorlel zat een referentie-elektrode, aan de rechter oorlel de grondelektrode.

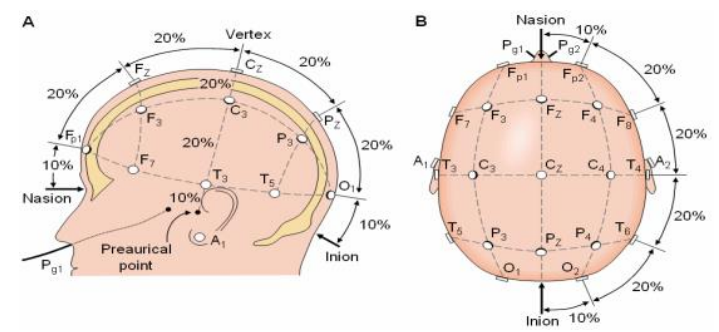

Figuur 1. Verschillende locaties op de schedel $(\mathrm{A}=$ oorlel, $\mathrm{C}=$ centraal, $\mathrm{P}=$ pariëtaal, $\mathrm{F}=$ frontaal, $\mathrm{Fp}=$ frontaal polaire en $\mathrm{O}=$ occipitaal). Figuur overgenomen uit American Electroencephalographic Society guidelines for standard electrode position nomenclature [21].

Er is gebruik gemaakt van twee computers. Elke computer was gekoppeld aan een proefpersoon. De computer werd gebruikt voor het registreren en opslaan van de hersengolven. Daarnaast werd de computer gebruikt voor de controle van het contact van de verschillende electroden met de hersengebieden. Er is tevens gebruik gemaakt van een hartslagmeter. Deze werd bevestigd aan de pols en de hartfrequentie werd gepresenteerd op het computerscherm en opgeslagen. De hartfrequentie werd weergegeven per amplitude. De amplitude van de hartfrequentie gaf de hoeveelheid hartslag aan voor een bepaalde frequentie. Hoe hoger de amplitude, des te meer hartslag voor die frequentie. Een hoge waarde voor een lage frequentie geeft een tragere hartslag aan, een hoge waarde voor een hoge frequentie geeft een snelle hartslag aan. De hartfrequentie werd gemeten met een specifiek kanaal van de Truscan van Deymed Diagnostics.

Er is daarnaast gebruikt gemaakt van de mobiele telefoons (smartphone) en geluidsoordopjes van de deelnemers. Hierop waren geluidsfragmenten te beluisteren. Alle fragmenten hadden een tijdsduur van ongeveer 3 minuten. Het mindfulness fragment had het onderwerp 'keuzeloze aandacht' [22]. Tijdens de 
rekentaak werden getallen door een mannenstem opgelezen die de proefpersoon diende te tellen en het aantal te onthouden. De analyses zijn uitgevoerd met het programma IBM SPSS Statistics, versie 19.

\section{Procedure}

Het onderzoek vond plaats in één van de onderzoeksruimten van het Transitorium van de Vrije Universiteit in Amsterdam. Er werd gestart met het aansluiten van het EEG systeem. Deze werd via een usb-poort aangesloten aan de computer. Op het computerscherm werden de verschillende electrode locaties en de hersenactiviteit weergegeven. Vervolgens werd de omtrek van het hoofd van elke proefpersoon gemeten en werd het juiste EEG kapje uitgezocht. De oren en het voorhoofd werden schoongemaakt met alcohol en 2 oorclips werden aan de oren bevestigd en in een kastje (de headbox) geplaatst. Deze headbox diende voor de verzending van alle signalen naar de computers. Vervolgens werden de gaatjes in de kapjes ingespoten met gel en werd met behulp van een stokje getracht contact te maken met de hoofdhuid door het haar opzij te schuiven. De locaties werden weergegeven op de computer en moesten blauw (goed contact) of groen (voldoende contact) van kleur zijn. Er werd tevens een hartslagmeter om de pols geplaatst. Aan de proefpersonen werd gevraagd om zo stil en ontspannen mogelijk te zitten en zo min mogelijk met de ogen te bewegen.

Alle metingen zijn uitgevoerd in koppels van twee personen. Dit waren steeds koppels van twee mannen of twee vrouwen. Alle metingen waren in de ochtend of in de middag en werden in een tijdsbestek van een week afgerond.

Allereerst werd een basismeting uitgevoerd. Het koppel van twee proefpersonen werd gevraagd om 5 minuten te ontspannen en niets te doen, met de ogen open. Vervolgens kreeg één van de twee personen het mindfulness fragment te horen, terwijl de ander de rekentaak uitvoerde (in het hoofd). Tijdens de rekentaak was de opdracht om het aantal getallen dat werd opgenoemd in het fragment in het hoofd te tellen en te onthouden. Als het fragment was afgelopen werd er niet naar de uitkomst van de rekentaak gevraagd. Tot slot luisterden beide proefpersonen tegelijk naar het meditatie fragment van drie minuten. $\mathrm{Zij}$ wisten van elkaar tijdens elke conditie wat 
de ander te horen kreeg.

Tijdens deze taken werden de

hartfrequentie en de EEG signalen gemeten en opgeslagen op de computer. De conditie binnen de proefpersoon was het luisteren naar het meditatie fragment of het rust fragment. De conditie tussen proefpersonen betrof één proefpersoon die mindfulness luisterde en de ander die een rekentaak uitvoerde, het beide luisteren naar het mindfulness fragment en het beide ontspannen en niets doen met de ogen geopend. $\mathrm{Na}$ afloop van het experiment zijn alle EEG- en hartfrequentie data in een SPSS data bestand opgeslagen.

\section{Statistische analyse}

Voordat de analyses zijn uitgevoerd zijn alle continue variabelen gecontroleerd op normaliteit. De EEG coherentie werd berekend als correlatie tussen de EEG data. Omdat de EEG data niet normaal waren verdeeld werd gekozen voor de nonparametrische Friedman Test. De hartfrequentie data waren wel normaal verdeeld zodat hierop een ANOVA met herhaalde metingen uitgevoerd kon worden.

Er werd een significantie grens van $p=.05$ aangehouden. Alle toetsen waren tweezijdig.

\section{Resultaten}

Om de eerste onderzoeksvraag te beantwoorden is de Friedman toets uitgevoerd. De analyse is uitgevoerd op de correlatie tussen de linker- en rechterhemisfeer over de vier hersengebieden gemiddeld (frontaal, temporaal, pariëtaal, occipitaal) en op de correlatie per hersengebied. Voor zowel de hersenen als geheel als de vier hersengebieden apart is er geen significant resultaat gevonden voor conditie. De beschrijvende statistieken van de variabelen staan in Tabel 1 en een overzicht van de resultaten staat weergegeven in Tabel 2. 
ISSN: 2589-8108ＤOI: https://doi.org/10.31739/GGZV.2019.2.39 C GGZ Vaktijdschrift, 2019;2(2):39-55 Knipschild en Verhagen $\quad$ Een onderzoek naar de fysiologische effecten van meditatie bij ongeoefende studenten

\begin{tabular}{lllll}
\hline Hersengebied & Conditie & $\boldsymbol{N}$ (personen) & $\begin{array}{l}\mathbf{5 0}^{\mathrm{e}} \text { percentiel } \\
\text { (mediaan) }\end{array}$ & $\begin{array}{l}\text { Gemiddelde } \\
\text { rang }\end{array}$ \\
\hline Geheel & Rust & 14 & .96 & 1.36 \\
& Mindfulness & 14 & .98 & 1.64 \\
Frontaal & Rust & 14 & 1.00 & 1.46 \\
& Mindfulness & 14 & 1.00 & 1.54 \\
Temporaal & Rust & 14 & 1.00 & 1.50 \\
& Mindfulness & 14 & 1.00 & 1.50 \\
Pariëtaal & Rust & 14 & 1.00 & 1.43 \\
& Mindfulness & 14 & 1.00 & 1.57 \\
Occipitaal & Rust & 14 & 1.00 & 1.50 \\
& Mindfulness & 14 & 1.00 & 1.50 \\
\hline
\end{tabular}

Tabel 1. Beschrijvende statistieken van EEG correlaties tussen linker- en rechterhemisfeer binnen een individu tijdens de rust conditie en de mindfulness conditie van het frontale hersengebied, het temporale, het pariëtale, het occipitale, en van de vier hersengebieden samen.

\begin{tabular}{llll}
\hline Hersengebied & $\boldsymbol{d} \boldsymbol{f}$ & $\boldsymbol{\chi}^{\mathbf{2}}$ & $\boldsymbol{p}$ \\
\hline Geheel & 1 & 1.143 & .29 \\
Frontaal & 1 & .08 & .78 \\
Temporaal & 1 & .00 & 1.00 \\
Pariëtaal & 1 & .29 & .60 \\
Occipitaal & 1 & .00 & 1.00 \\
\hline
\end{tabular}

Tabel 2. Overzicht Friedman toets m.b.t. onderzoeksvraag 'wordt de intrapersoonlijke EEG correlatie tussen linker- en rechter hemisfeer gemiddeld over alle locaties en apart voor frontale, temporale, pariëtale en occipitale

afleidingen hoger tijdens meditatie.

Om de tweede onderzoeksvraag te toetsen is er een ANOVA met herhaalde metingen uitgevoerd. Dit werd gedaan door de gemiddelde hartfrequentie waarden van een individu in rust te vergelijken met de hartfrequentie waarden tijdens mindfulness. Er is geen significant resultaat maar wel een trend gevonden voor een afname van de hartfrequentie tijdens mindfulness. De gemiddelden en standaard deviaties staan weergegeven in Tabel 3 en de resultaten in Tabel 4. 
ISSN: 2589-8108ＤOI: https://doi.org/10.31739/GGZV.2019.2.39 C GGZ Vaktijdschrift, 2019;2(2):39-55 Knipschild en Verhagen $\quad$ Een onderzoek naar de fysiologische effecten van meditatie bij ongeoefende studenten

\begin{tabular}{llll}
\hline Conditie & $\boldsymbol{N}$ (personen) & $\begin{array}{l}\text { Gemiddelde } \\
\text { hartfrequentie }(\boldsymbol{\mu V})\end{array}$ & Standaard deviatie \\
\hline Rust conditie & 14 & 80.46 & 71.76 \\
Mindfulness conditie & 14 & 56.54 & 45.67 \\
\hline
\end{tabular}

Tabel 3. Beschrijvende statistiek van de amplitude van de hartfrequentie tijdens de rustconditie en de mindfulness conditie, waarbij geldt: een hogere amplitude is een snellere hartslag.

\begin{tabular}{llllll}
\hline Hartfrequentie & $\begin{array}{l}\text { Willks' } \\
\text { Lambda }\end{array}$ & $\boldsymbol{d} \boldsymbol{f}$ & $\boldsymbol{F}$ & $\boldsymbol{p}$ & partial \\
& & & & $\boldsymbol{\eta}^{\mathbf{2}}$ \\
\hline Geheel 14 individuen & .76 & 1,13 & 4.11 & .06 & .24 \\
\hline
\end{tabular}

Tabel 4. Resultaten ANOVA. Onderzoeksvraag 'gaat de hartfrequentie van een individu omlaag tijdens meditatie?

Om de derde onderzoeksvraag te toetsen is de Friedman toets uitgevoerd om te testen of er een significant verschil in interpersoonlijke EEG correlatie waarden tussen linker- en rechterhemisfeer is tussen de drie condities (rust, mindfulness en 'mindfulness versus rekenen'). Er is geen significant resultaat gevonden in correlatie van de interpersoonlijke algemene hersenactiviteit voor conditie. De beschrijvende statistieken staan weergegeven in Tabel 5 en de resultaten staat weergegeven in Tabel 6.

\begin{tabular}{|c|c|c|c|}
\hline Conditie & $\begin{array}{l} \\
\text { (koppels) }\end{array}$ & $\begin{array}{l}\mathbf{5 0}^{\mathrm{e}} \\
\text { percentiel } \\
\text { (mediaan) }\end{array}$ & $\begin{array}{l}\text { Gemid } \\
\text { delde } \\
\text { rang }\end{array}$ \\
\hline Rust & 7 & .90 & 2.29 \\
\hline $\begin{array}{l}\text { 'Mindfulness } \\
\text { versus }\end{array}$ & 7 & .94 & 1.86 \\
\hline \multicolumn{4}{|l|}{ Rekenen' } \\
\hline Mindfulness & 7 & .92 & 1.86 \\
\hline
\end{tabular}

Tabel 5. Beschrijvende statistiek van de EEG correlaties tussen personen op het moment dat twee individuen tegelijk in meditatieve toestand zijn (Mindfulness), als twee personen tegelijk niet in 
meditatieve toestand zijn (Rust) en als slechts één van beiden in meditatieve toestand is (Mindfulness versus Rekenen).

\begin{tabular}{lccc}
\hline EEG & $\boldsymbol{d} \boldsymbol{f}$ & $\chi^{2}$ & $\boldsymbol{p}$ \\
waarden & & & \\
\hline Geheel 7 & 2 & .86 & .65 \\
koppels & & & \\
\hline
\end{tabular}

Tabel 6. Resultaten Friedman toets onderzoeksvraag 'wat gebeurt er met de interpersoonlijke EEG correlatie tussen twee individuen als zij tegelijk in meditatieve toestand zijn, tegelijk niet in meditatieve toestand zijn en als een van beide in meditatieve toestand is?'

\section{Discussie}

In deze studie zijn drie onderzoeksvragen getoetst. De eerste vraag was: wordt de EEG correlatie binnen de hersenen van een individu beïnvloed tijdens meditatie? De tweede onderzoeksvraag luidde: gaat de hartfrequentie van een individu omlaag tijdens meditatie? De derde onderzoeksvraag was: wat gebeurt er met de interpersoonlijke EEG correlatie tussen de algemene hersenactiviteit van twee individuen als zij tegelijk in meditatieve toestand zijn, tegelijk niet in meditatieve toestand zijn en als een van beide in meditatieve toestand is? In dit onderzoek naar EEG correlaties en hartfrequenties zijn geen significante resultaten gevonden.

Binnen het individu is er tijdens meditatie voor geen enkel gebied een significante toename gevonden in EEG correlatie tussen de linker- en rechterhemisfeer. Daarnaast is alleen een trend maar geen significante afname in hartfrequentie gemeten binnen een individu tijdens meditatie. Dit was niet volgens de verwachting op basis van de in de inleiding beschreven onderzoeken $[14,17,18]$. Over de gehele hersenen is er wel een kleine toename in de gemiddelde EEG correlatie te zien, maar niet genoeg om van een significante toename te spreken. De resultaten laten voor de aparte hersengebieden geen toename in EEG correlatie tussen linker- en rechterhemisfeer zien tijdens meditatie. De hartfrequentie neemt volgens de verwachting wel af tijdens meditatie, maar dit is slechts een trend.

Er is tevens geen significant resultaat gevonden voor de derde onderzoeksvraag over interpersoonlijke EEG correlatie tussen de algehele hersenactiviteit over de condities rust, mindfulness en 'mindfulness 
versus rekenen'. De 'mindfulness versus rekenen' conditie had de hoogste gemiddelde EEG correlatie waarde en de mindfulness conditie de laagste. Dit was niet volgens de verwachting op basis van de onderzoeken beschreven in de inleiding, waarbij werd verwacht dat de mindfulness conditie de hoogste correlatie zou hebben en 'mindfulness versus rekenen' de laagste. De reden voor deze verwachting was allereerst dat op basis van de onderzoeken een hogere EEG correlatie wordt verwacht als twee personen eenzelfde taak uitvoeren ten opzichte van twee personen die elk een andere taak uitvoeren. Bij de mindfulness en de rustcondities werd daardoor een hogere interpersoonlijke EEG correlatie verwacht dan bij de 'mindfulness versus rekenen' conditie. Daarbij komt de verwachting dat mindfulness voor een hogere EEG correlatie zorgt ten opzichte van geen mindfulness (onderzoeksvraag 1) en om deze reden werd verwacht dat de mindfulness conditie een hogere interpersoonlijke EEG correlatie zou hebben dan de rustconditie $[9,11,12]$.

Er is gedurende het gehele onderzoek gebleken dat meditatie weinig heeft veranderd in de lichamelijke en geestelijke toestand van de proefpersonen. Een reden hiervoor zou kunnen zijn dat de proefpersonen in dit onderzoek weinig tot geen ervaring hadden met meditatie. In de intra-hersenonderzoeken van Sudsuang et al. [18] en Travis en Wallace [17] hadden alle proefpersonen voordat ze begonnen aan het onderzoek al ervaring met meditatie. Dit kon zijn door jarenlange persoonlijke ervaring of middels een training voorafgaand aan het onderzoek. In dit onderzoek is daar geen sprake van geweest. Het is goed mogelijk dat het de proefpersonen, door gebrek aan ervaring, niet is gelukt om in een meditatieve toestand te komen. Dit zou een logische verklaring kunnen zijn voor het feit dat de rust conditie nauwelijks verschilt van de mindfulness conditie. De rust conditie is dan immers bijna hetzelfde. Dit gebrek aan ervaring van meditatie heeft mogelijk ook voor ruis in het interpersoonlijke brein onderzoek gezorgd. De proefpersonen werden opgedeeld in koppels. Als het echter één van de twee proefpersonen niet lukte om in meditatieve toestand te komen, was een gunstige uitkomst voor dit onderdeel al niet mogelijk. De proefpersonen dienen allebei in meditatieve toestand te komen om te meten of de EEG correlatie daarvan omhoog zou gaan. Het is niet te controleren of men 
daadwerkelijk in meditatieve toestand is geweest, wat het moeilijk maakt om hierover conclusies te trekken.

Er zijn een aantal zwaktes in dit onderzoek aan te wijzen, die er mogelijkerwijs voor hebben gezorgd dat er ruis in de data is ontstaan. Een limitatie van dit onderzoek is dat er wellicht te weinig proefpersonen waren voor de interpersoonlijke hersen analyses. De proefpersonen waren opgedeeld in zeven koppels. Daarmee zijn de analyses uitgevoerd. Dit kan te weinig zijn omdat er fouten gemaakt kunnen worden tijdens een meting en daarvoor kan in dit geval moeilijk worden gecontroleerd. Daarbij komt dat een deel van de statistische analyses non-parametrisch was. Als er meer proefpersonen hadden deelgenomen was de kans groter geweest dat er voor alle analyses parametrische toetsen uitgevoerd hadden kunnen worden.

Eén van de sterke punten uit dit onderzoek is dat de proefpersonen aselect aan condities zijn toegewezen. Hierdoor is er bijvoorbeeld bij de rekentaak geen onderscheid gemaakt tussen personen die goed of slecht konden rekenen. Als dit niet het geval was geweest hadden wellicht alleen de goede rekenaars voor deze taak gekozen waardoor er ruis in de data had kunnen ontstaan. Een ander sterk punt is dat er gewerkt is met een kleine leeftijdsspanne. De minimum leeftijd was 19 jaar en de maximum leeftijd was 24 jaar. Dit betekent dat de hersenen van de proefpersonen in eenzelfde staat van ontwikkeling waren. Hierdoor zijn de EEG correlaties van de proefpersonen goed met elkaar te vergelijken. Thatcher [23] onderzocht de ontwikkeling van EEG coherenties in het brein van individuen tussen de 2 maanden en 26 jaar oud. Naarmate de persoon ouder werd, nam de coherentie toe en verbindingen binnen en tussen hersengebieden werden gedetailleerder. Dit was vooral het geval bij het frontale deel van het brein. Hersenen veranderen voortdurend en daarom is het belangrijk om een niet te brede leeftijdsspanne te gebruiken voor hersenonderzoek.

Hersenonderzoek is belangrijk voor veel verschillende aspecten binnen het menselijk leven. Uit de eerder beschreven onderzoeken $[14,17,18]$ is gebleken dat meditatie wel degelijk invloed heeft op EEG correlaties in de hersenen van een individu. Als dit na meer onderzoek daadwerkelijk het geval blijkt te zijn, betekent dat dat men door middel van 
meditatie ervoor kan zorgen dat de hersenenhelften binnen een individu beter samenwerken. De toename van EEG correlatie zorgt voor een toename van het functionele samenspel tussen neurale netwerken, waardoor men efficiënter en beter kan functioneren [3].

\section{Daarnaast zou interpersoonlijk} hersenonderzoek een grote invloed kunnen hebben op het begrijpen van sociale interacties. Als blijkt dat men elkaars hersengolven onbewust beïnvloedt als twee mensen hetzelfde doen zou dit zou erop kunnen wijzen dat de mens door samen te werken een toename in EEG correlatie creëert, wat zorgt voor een toename tussen het samenspel tussen de neurale netwerken[4, 9-12, 24]. Dit is relevant omdat men het onderwijs hierop zou kunnen aanpassen door kinderen meer te laten samenwerken. Daarnaast kan men werknemers in bedrijven meer samen laten werken aan projecten.

Tot slot is hartfrequentie een belangrijke maat voor de menselijke gezondheid. Als na verder onderzoek blijkt dat hartfrequentie omlaag gaat tijdens meditatie zal dit goed kunnen zijn voor het menselijk welzijn. Uit onderzoek is gebleken dat een verhoogde hartfrequentie leidt tot een verhoogde kans op cardiovasculaire ziekten. Een verlaging van diezelfde hartfrequentie kan deze kans doen afnemen $[19,20]$.

In de toekomst zal het goed zijn om het huidige onderzoek nog een keer uit te voeren, maar dan met proefpersonen die minimaal vijf jaar ervaring hebben met meditatie. Daarnaast zouden er meer proefpersonen mee moeten doen, vooral voor het interpersoonlijk brein onderzoek.

\section{Referenties}

1. Dunbar, R.I., The social brain hypothesis. Evolutionary Anthropology: Issues, News, and Reviews: Issues, News, and Reviews, 1998. 6(5): p. 178-190.

2. Sawaguchi, T. and H. Kudo, Neocortical development and social structure in primates. Primates, 1990. 31(2): p. 283-289.

3. Weiss, S. and H.M. Mueller, The contribution of EEG coherence to the investigation of language. Brain and language, 2003. 85(2): p. 325343 DOI: $10.1016 / \mathrm{s} 0093$ 934x(03)00067-1.

4. Labooy-Speksnijder, C., J. Deijen, and H. Engelbregt, Persoonlijkheid en Hersenconnectiviteit, een nieuwe uitdaging? GGZ Vaktijdschrift, 2019. 2(1): p. 29-40 DOI: https://doi.org/10.31739/GGZV.201 9.1.29.

5. Scholkmann, F., L. Holper, U. 
Wolf, and M. Wolf, A new methodical approach in neuroscience: assessing interpersonal brain coupling using functional near-infrared imaging (fNIRI) hyperscanning. Frontiers in human neuroscience, 2013. 7: $\mathrm{p}$. 813.

6. Wolf, U., S. Klein, M. Wolf, and F. Scholkmann, Effects of inner and heard speech in arts speech therapy on cerebral oxygenation and hemodynamics. 2013.

7. Günther, W., N. Müller, W. Trapp, C. Haag, A. Putz, and A. Straube, Quantitative EEG analysis during motor function and music perception in Tourette's syndrome. European archives of psychiatry and clinical neuroscience, 1996. 246(4): p. 197-202.

8. Burgess, A.P., On the interpretation of synchronization in EEG

hyperscanning studies: a cautionary note. Frontiers in human neuroscience, 2013. 7: p. 881 DOI: 10.3389/fnhum.2013.00881.

9. Dumas, G., J. Nadel, R.

Soussignan, J. Martinerie, and L. Garnero, Inter-brain synchronization during social interaction. PloS one, 2010. 5(8): p. e12166 DOI:

10.1371/journal.pone.0012166.

10. J., E.H., H.F. Alderse Baas, S.D. Grauw, and J.B. Deijen, Brain Activity during joint and individual Mindfulness Meditation, a controlled EEG Study. 2019.

11. Jiang, J., B. Dai, D. Peng, C. Zhu, L. Liu, and C. Lu, Neural synchronization during face-to-face communication. Journal of Neuroscience, 2012. 32(45): p. 16064-16069 DOI: 10.1523/JNEUROSCI.292612.2012 .
12. Spiegelhalder, K., S. Ohlendorf, W. Regen, B. Feige, L.T. van Elst, C. Weiller, J. Hennig, M. Berger, and O. Tüscher, Interindividual synchronization of brain activity during live verbal communication. Behavioural brain research, 2014. 258: p. 75-79 DOI: 10.1016/j.bbr.2013.10.015.

13. Kabat-Zinn, J., An outpatient program in behavioral medicine for chronic pain patients based on the practice of mindfulness meditation: Theoretical considerations and preliminary results. General hospital psychiatry, 1982. 4(1): p. 33-47 DOI: 10.1016/01638343(82)90026-3.

14. Chiesa, A. and A. Serretti, $A$ systematic review of neurobiological and clinical features of mindfulness meditations. Psychological medicine, 2010. 40(8): p. 1239-1252 DOI: $10.1017 / \mathrm{S} 0033291709991747$.

15. Grossman, P., L. Niemann, S. Schmidt, and H. Walach, Mindfulness-based stress reduction and health benefits: A metaanalysis. Journal of psychosomatic research, 2004. 57(1): p. 35-43 DOI: $10.1016 / \mathrm{S} 0022-$ 3999(03)00573-7.

16. Travis, F. and C. Pearson, Pure consciousness: distinct phenomenological and physiological correlates of "consciousness itself". International Journal of Neuroscience, 2000. 100(1-4): p. 77-89.

17. Travis, F. and R.K. Wallace, Autonomic patterns during respiratory suspensions: possible markers of transcendental consciousness. Psychophysiology, 1997. 34(1): p. 39-46 DOI: 
ISSN: 2589-8108ＤOI: https://doi.org/10.31739/GGZV.2019.2.39 C GGZ Vaktijdschrift, 2019;2(2):39-55

Knipschild en Verhagen $\quad$ Een onderzoek naar de fysiologische effecten van meditatie bij ongeoefende studenten

10.1111/j.1469-

8986.1997.tb02414.x.

18. Sudsuang, R., V. Chentanez, and K. Veluvan, Effect of Buddhist meditation on serum cortisol and total protein levels, blood pressure, pulse rate, lung volume and reaction time. Physiology \& Behavior, 1991. 50(3): p. 543-548 DOI: $10.1016 / 0031-$ 9384(91)90543-w.

19. Palatini, P. and S. Julius, Elevated heart rate: a major risk factor for cardiovascular disease. Clinical and experimental hypertension, 2004. 26(7-8): p. 637-644 DOI: 10.1081/ceh-200031959.

20. Liang, M., A. Puri, and G. Devlin, Heart rate and cardiovascular disease: an alternative to beta blockers. Cardiology research and practice, 2009. 2009: p. 179350 DOI: $10.4061 / 2009 / 179350$.
21. Sharbrough, F., Chatrian, GE, Lesser, RP, Liiders, H., Nuwer, M. and Picton, TW American LEG Society guidelines for standard electrode position nomenclature. J. Clin. Neurophysiol, 1991. 8: p. 200-202.

22. Puddicombe, A., Get Some Headspace: How Mindfulness Can Change Your Life in Ten Minutes a Day. 2012, Macmillan.

23. Thatcher, R.W., Maturation of the human frontal lobes: Physiological evidence for staging.

Developmental Neuropsychology, 1991. 7(3): p. 397-419.

24. Coomans, E., I. Geraedts, J.B.

Deijen, D. Keeser, O. Pogarell, and H.J. Engelbregt, Inter-Subject Brain Coherence in Healthy Dyads during Cooperation, Stress and Mindfulness, and the Influence of Personality: an EEG Hyperscanning Study. 2019. 